UDK 1 Leibniz, G. W.

$113 / 119$

Primljeno: 30. 9. 2020.

Prihvaćeno: 1. 3. 2021.

Izvorni znanstveni rad

\title{
MAKSIMALNA KONTINGENTNA ČINJENICA U LEIBNIZOVSKIM KOZMOLOGIJSKIM ARGUMENTIMA
}

\author{
Goran LOJKIĆ \\ Institut za filozofiju \\ Ulica grada Vukova 54, 10000 Zagreb \\ goran@ifzg.hr
}

\section{Sažetak}

Leibnizovski kozmologijski argumenti razred su kozmologijskih argumenata za opstojnost metafizički prvoga uzroka, kojih je definirajuće obilježje primjena nekoga širokoga eksplanacijskog načela ili pak ne-lokalnoga načela kauzalnosti na tzv. maksimalnu kontingentnu činjenicu, tj. kontingentnu činjenicu koja sadržava ili povlači svaku kontingentnu činjenicu relevantne vrste. Jedna je od strategija za napad na leibnizovski argument stoga argumentirati da odgovarajuća maksimalna kontingentna činjenica ne postoji. Rad opisuje dva načelna načina na koja se to može pokušati učiniti. Prvi je zanijekati da je maksimalna kontingentna činjenica legitimna cjelina činjenica, drugi je zanijekati opstojnost kontingentnih činjenica općenito. Iznosi se nekoliko alternativnih formulacija tvrdnje o postojanju maksimalne kontingentne činjenice, njihova pozadinska teorijska motivacija i načini na koje pojedine formulacije izbjegavaju prigovore. Argumentira se da prigovori koji se odnose na maksimalnu kontingentnu činjenicu nisu ozbiljna prijetnja leibnizovskim argumentima za opstojnost prvoga uzroka.

Ključne riječi: kozmologijski argumenti, leibnizovski kozmologijski argument, kontingentnost, maksimalna kontingentna činjenica, nužna opstojnost, prvi uzrok.

\section{Uvod}

Standardni kozmologijski argumenti za Božju opstojnost mogu se ugrubo podijeliti u dva dijela ili stadija: prvi dio argumenta (egzistencijski stadij) pokušava dokazati opstojnost metafizički "prvoga uzroka«, dok drugi dio (identifikacijski stadij) pokušava pokazati da prvi uzrok jest Bog, tj. da (nužno) 
posjeduje dovoljno klasičnih božanskih atributa kojima se može opravdati njegovu identifikaciju kao Boga, kako se riječ »Bog« tradicionalno razumije u naravnoj teologiji. ${ }^{1}$ Egzistencijska faza kozmologijskih argumenata počiva na trima središnjim tvrdnjama, iz kojih, uz određene pozadinske pretpostavke poput logičkih i mereologijskih aksioma, opstojnost prvoga uzroka tipično vrlo jednostavno slijedi. Obrana tih triju središnjih tvrdnji stoga tvori glavni dio prvoga stadija kozmologijskoga argumenta.

Prva središnja tvrdnja kozmologijskoga argumenta konstatacija je određene »velike činjenice«, što obično uključuje opis neke "globalne« ili »kozmičke« karakteristike svijeta za koju tražimo objašnjenje. ${ }^{2}$ Ovisno o argumentu, velika činjenica može biti primjerice to da se neke stvari u svijetu mijenjaju (kao u slučaju prvoga od slavnih pet putova Tome Akvinskoga) ili, recimo, to da je svemir počeo postojati prije konačno mnogo vremena (u slučaju kalām kozmologijskoga argumenta). Druga središnja tvrdnja neki je oblik metafizičkoga načela kauzalnosti ili načela objašnjenja prema kojem svaki član neke za argument relevantne kolekcije činjenica - kolekcije činjenica koja uključuje veliku činjenicu kojoj tražimo objašnjenje - ima uzrok ili objašnjenje odgova-

1 Usp. William L. ROWE, Philosophy of Religion: An Introduction, Wadsworth, 2007., 20. Nazivi »egzistencijski stadij« (existence stage) i »identifikacijski stadij« (identification stage) preuzeti su iz: Timothy O'CONNOR, Theism and Ultimate Explanation: The Necessary Shape of Contingency, Chichester, 2012. Podjela na dva dijela kozmologijskoga argumenta donekle je gruba jer, ovisno već o posebnim inačicama argumenta, dokazati opstojnost prvoga uzroka u prvom stadiju argumenta upravo znači dokazati opstojnost entiteta koji posjeduje određene standardne božanske atribute: bića koje je actus purus i stoga nepromjenjivo, na primjer, ili bića koje postoji metafizički (ili čak apsolutno) nužno i sl. Da prvi uzrok zadovoljava barem neka od daljnjih definicijski nužnih uvjeta da bismo ga smatrali Bogom iz toga neposredno slijedi - opet, ovisno u detaljima o konkretnoj inačici kozmologijskoga argumenta.

2 Riječ činjenica ima zloglasno široko i neujednačeno značenje u filozofijskoj literaturi i u različitih autora može označavati vrlo različite vrste teorijskih entiteta. U tekstu taj izraz stoga uglavnom rabimo u opuštenom i teorijski neobvezujućem smislu, ne povlačeći razliku između, recimo, situacija, uspostavljenih stanja stvarī, istinitih propozicija i drugih vrsta entitetā koje su filozofi skloni nazivati činjenicama i ne obvezujući se ni na koju posebnu pozadinsku ontologiju činjenica. No, kako ćemo kasnije vidjeti, razlika koju pojedini autori povlače između, na primjer, situacija s jedne i istinitih propozicija s druge strane u nekim je formulacijama kozmologijskih argumenata ključna za odgovor na određene vrste prigovora argumentu. Radi jasnoće napominjemo da riječ propozicija, u skladu s raširenom praksom i nazivljem autorā koje spominjemo, u radu dosljedno rabimo za apstraktne entitete koji su, prema standardnom pogledu, primarni nositelji istinitosnih vrijednosti. Propozicije se mogu shvatiti kao ono što se izražava bilo istinitim bilo neistinitim rečenicama, tj. kao smisao ili informacijski sadržaj rečenica. U standardnom primjeru, »Snow is white « $\mathrm{i} »$ Der Schnee ist weiß«, iako rečenice različitih jezika, izražavaju istu propoziciju - naime, propoziciju da je snijeg bijel - i obje su istinite upravo zato što je propozicija koju izražavaju istinita propozicija. Dakako, ne pretpostavljamo time ujedno da propozicije (i apstraktni entiteti općenito) doista postoje. 
rajuće vrste. ${ }^{3}$ Primjer bi bilo načelo prema kojem svaka promjena, tj. svaka aktualizacija potencija, mora imati uzrok u nečemu što sámo postoji aktualno (u spomenutom Tominu argumentu) ili, recimo, načelo prema kojem svaka stvar koja je započela postojati ima neki djelatni uzrok svoje opstojnosti (u kalāmu). Treća je središnja tvrdnja svojevrsno načelo regularnosti ili utemeljenja, koje ili isključuje metafizičku mogućnost za argument u pitanju relevantnih neutemeljenih (non-well-founded) kauzalnih i eksplanacijskih struktura poput kauzalnih petlji i cirkularnih objašnjenja ili barem prema kojem su takve strukture (nužno) eksplanacijski nepotpune i koje stoga implicira (obično u konjunkciji s pripadajućim načelom uzročnosti ili objašnjenja) da i one same moraju imati neki daljnji uzrok ili objašnjenje. Primjeri su načela regularnosti načelo prema kojem se nijedan potpuni per se uređen kauzalni niz ne može sastojati samo od drugotnih ili instrumentalnih uzroka (u Tominu argumentu) i načelo da nijedna stvar ne može biti djelatni uzrok same sebe (između ostalih, u kalām argumentu). Dakako, za sve tri tvrdnje postoji širok raspon mogućih varijacija i kvalifikacija i moguće su veće ili manje razlike u njihovim formulacijama, ovisno, između ostaloga, o retoričkim potrebama, teorijskom kontekstu i različitim pozadinskim razmatranjima. ${ }^{4}$ Ovisno o konkretnom obliku tih triju sre-

3 Ovdje rabimo termin kolekcija radije nego skup ili razred jer kolekcija u pitanju može biti "prevelika « da bi bila skup ili čak pravi razred (u tehničkom značenju tih izraza). Neke aksiomatske teorije skupova, poput teorija NBG i MK, razlikuju skupove (tj. razrede koji su i sami elementi drugih razreda, npr. razred prirodnih brojeva) i prave razrede (razrede koji nisu elementi, koji su "preveliki« da bi bili skupovi, npr. razred rednih brojeva). Primjerice, kolekcija svih rečenica hrvatskoga jezika jest skup, ali kolekcija svih istinitih propozicija nije skup (usp. Patrick GRIM, There Is No Set of All Truths, u: Analysis, 44 (1984.) $4,206-208)$. No ona nije ni pravi razred. Naime, ne postoji razred svih pravih razreda, dok za svaki pravi razred $C$ postoji neka jedinstvena istinita propozicija, npr. propozicija da je C istovjetan samomu sebi (usp. Alexander R. PRUSS, Actuality, Possibility, and Worlds, New York, 2011., 158-159). Slijedi iz toga da je kolekcija svih istinitih propozicija »veća« ili »brojnija« od bilo kojega razreda. Dopustimo li, što se ne čini problematičnim, kontingentne propozicije s proizvoljnim nužnim propozicijama kao svojim potpropozicijama (poput, primjerice, konjunktivne propozicije da je Sokrat mudar i svi neženje neoženjeni), trivijalno slijedi da isto vrijedi i za kolekciju svih kontingentno istinitih propozicija. Argumenti, neovisni o toj pretpostavci, da kolekcija svih kontingentno istinitih propozicija ne tvori skup mogu se naći u: Alexander R. PRUSS, The Principle of Sufficient Reason. A Reassesment, Cambridge, 2006., 100; Richard M. GALE - Alexander R. PRUSS, A Response to Oppy, and to Davey and Clifton, u: Religious Studies, 38 (2002.) 1, 89-99, 99 (bilj. 7).

4 Načelo regularnosti u nekima je formulacijama kozmologijskoga argumenta tako samo implicitno pretpostavljeno, u nekima je eksplicitno navedeno, a u nekima je pak asimilirano unutar eksplikacije prikladnoga kauzalnog ili eksplanacijskog načela. Također, načelo regularnosti ponegdje je konjunkcija nekoliko različitih tvrdnji, svaka od kojih odnosi se na drukčiju vrstu neutemeljenih kauzalnih ili eksplanacijskih struktura. $\mathrm{Na}$ primjer, Robert C. KOONS, A New Look at the Cosmological Argument, u: American Philosophical Quarterly, 34 (1997.) 2, 193-211 kao zasebne aksiome iznosi i aksiom univerzalnosti kauzalnosti, prema kojem svaka potpuno kontingentna činjenica ima uzrok, i 
dišnjih tvrdnji i njihovoj teorijskoj ulozi u dokazu opstojnosti prvoga uzroka, kozmologijski se argumenti mogu klasificirati u tri velike skupine: tomističke, kalām i leibnizovske kozmologijske argumente. ${ }^{5}$

$\mathrm{U}$ ovom radu detaljnije opisujemo »veliku činjenicu« leibnizovskih kozmologijskih argumenata, tj. ono što ćemo nazvati »maksimalna kontingentna činjenica«. Izlažemo nekoliko različitih formulacija tvrdnje o postojanju maksimalne kontingentne činjenice u suvremenoj literaturi, analizirajući pozadinsku teorijsku motivaciju različitih artikulacija te tvrdnje i načine na koje pojedine formulacije izbjegavaju određene standardne prigovore leibnizovskomu kozmologijskom argumentu. Cilj nam je pokazati da prigovori koji se odnose na maksimalnu kontingentnu činjenicu ne predstavljaju ozbiljan izazov leibnizovskim argumentima za opstojnost prvoga uzroka. ${ }^{6}$

\section{Maksimalna kontingentna činjenica}

Definirajuća odlika leibnizovskih kozmologijskih argumenata (argumenata LK) primjena je nekoga vrlo širokoga eksplanacijskog načela, poput primjerice načela dostatnoga razloga, ili pak prikladnoga ne-lokalnog načela kauzalnosti na »maksimalnu kontingentnu činjenicu«, tj. činjenicu koja (u nekom primjerenom smislu) uključuje, sadržava ili logički povlači svaku kontingentnu činjenicu relevantne vrste - naime, svaku kontingentnu činjenicu na koju se eksplanacijsko ili kauzalno načelo u pitanju odnosi ${ }^{7}$ čime se pokušava dokazati

aksiom odvojene opstojnosti (separate existence) uzroka i učinka, prema kojem se uzrok i učinak ne mogu mereologijski preklapati, tj. ne mogu imati zajednički mereologijski dio, i koji stoga u Koonsovu argumentu ima, u konjunkciji s mereologijskim aksiomima, ulogu načela regularnosti. S druge strane, William Lane CRAIG, Reasonable Faith. Christian Truth and Apologetics, Wheaton, 2007., $160 \mathrm{u}$ svojoj formulaciji leibnizovskoga kozmologijskog argumenta načelo objašnjenja i načelo regularnosti iznosi unutar iste premise: »Sve što postoji ima objašnjenje svoje opstojnosti, bilo u nužnosti vlastite naravi bilo u vanjskom uzroku.« Odnos između spomenutih triju središnjih tvrdnji na kojima počiva egzistencijski stadij kozmologijskih argumenata može u pojedinim inačicama argumenta biti puno složeniji nego što sugeriramo tekstom. Vidi, primjerice, bilj. 25. Sve citate u tekstu preveo je s engleskoga autor rada.

5 Usp. Alexander R. PRUSS, The Leibnizian Cosmological Argument, u: William Lane Craig - James P. Moreland (ur.), The Blackwell Companion to Natural Theology, Chichester, 2009., 24-100, 25.

6 U tekstu ponegdje govorimo o leibnizovskim kozmologijskim argumentima, ponegdje pak o inačicama leibnizovskoga kozmologijskog argumenta, no razlika je samo stilska i ne nosi nikakvo daljnje značenje. Pitanje je li pojedine konkretne formulacije argumenta prikladnije smatrati samo različitim inačicama istoga argumenta ili pak različitim iako srodnim argumentima za naše svrhe možemo ignorirati.

7 Što su kontingentne činjenice »relevantne vrste« ovisi, dakako, o pojedinim konkretnim formulacijama argumenta, prije svega o tome u kojim je terminima formulirano 
opstojnost metafizički (ili čak apsolutno) nužnoga konkretnog bića, tradicionalno zvanoga »prvi uzrok«, kao metafizički krajnjega utemeljenja (kontingentne) stvarnosti. ${ }^{8}$ Leibnizovski kozmologijski argumenti dolaze $u$ različitim inačicama, no prva središnja tvrdnja svake od njih - tvrdnja o postojanju određene velike činjenice za koju se traži objašnjenje - eksplicitno naglašava neki vid globalnoga kontingentnog ustrojstva svijeta. ${ }^{9}$

U pozadini argumenata LK, kao i ostalih kozmologijskih argumenata iz kontingentnosti, naše su snažne modalne intuicije da svijet (shvaćen u najširem smislu kao stvarnost ili zbilja općenito) nije nužno upravo ovakvim kakvim jest, da bi svijet u mnogim svojim vidovima i na različite načine mogao biti drukčijim nego što je doista slučaj. U danas standardnoj terminologiji, ovo nije jedini mogući svijet. Računalo na kojem je napisan ovaj tekst moglo je nikada ne biti proizvedeno ili je već moglo biti uništeno; svijet bi mogao biti takvim da tekst koji upravo čitate nikada nije napisan ili da je napisan ranije ili kasnije nego što doista jest; postoji mogući svijet u kojem ovaj tekst nikada niste uzeli u ruke i u kojem čitate tekst koji, u svijetu kakav zbiljski jest, nikada nije napisan. Čak i ako bi opstojnost svakoga naizgled kontingentnoga predmeta, svako njegovo naizgled kontingentno svojstvo i svaka naizgled kontingentna relacija u kojoj stoji, svaki naizgled kontingentan događaj, svako naizgled kontingentno uspostavljeno stanje stvarī i sl. bili fizički nužnima npr. stoga jer su (u primjerenom smislu) deterministički učinci fundamentalnih fizikalnih entiteta i zakonā (koji god oni bili) - ti bi predmeti, događaji i stanja stvarī i dalje bili, čini nam se, metafizički kontingentnima. Naime, što

relevantno eksplanacijsko ili kauzalno načelo. Tipični su primjeri, recimo, situacije, propozicije i stanja stvarī (vidi bilj. 12-14). Primjerice, ako je načelo u pitanju to da svaka kontingentno istinita propozicija ima objašnjenje, odgovarajuća maksimalna kontingentna činjenica bit će nešto poput konjunkcije svih kontingentno istinitih propozicija.

8 Usp. Alexander R. PRUSS, The Leibnizian Cosmological Argument, 25-26. Pod izrazom »ne-lokalno načelo kauzalnosti« imamo na umu kauzalna načela koja nisu ograničena samo na lokalizirane pojedinačnosti određenoga tipa (npr. supstancije ili događaje), već se odnose i na proizvoljno složene cjeline (npr. konfiguracije i općenito mereologijske sume) tih pojedinačnosti (npr. mereologijske agregate supstancija, lance događajā i sl.). Usp. Isto, 60-61. U inačicama argumenta LK kojima se želi izbjeći tvrdnja da množina svih relevantnih kontingentnih činjenica tvori cjelinu, tj. zaseban složeni entitet, ne-lokalno načelo kauzalnosti moralo bi biti takvo da se odnosi na proizvoljne množine kontingentnih činjenica, ne samo na njihove cjeline. Ta će napomena biti jasnija na kraju drugoga odsječka.

9 Zapravo, riječ je o ponešto preuskoj karakterizaciji argumenata LK. Kako ćemo vidjeti, postojanje kontingentnih činjenica nije nužan uvjet uspješnosti leibnizovskih argumenata jer se argumenti posve analogne strukture mogu bez gubitka plauzibilnosti formulirati i samo u terminima distinkcije između apsolutne nužnosti - tradicionalnim rječnikom, nužnosti $a$ se - i izvedene ili uvjetne nužnosti. 
god bili osnovni gradivni elementi koji konstituiraju fizičku stvarnost (ova ili ona fizikalna polja i čestice, na primjer) i što god bili temeljni zakoni prirode, izgleda očitim da bi svijet mogao biti takvim da je svemir građen od nekih drugih osnovnih gradivnih sastavnica i upravljan drukčijim temeljnim zakonima. Klasičnu mehaniku više ne smatramo istinitim opisom fizičkoga svijeta, no newtonovski se svemir čini metafizički mogućim; prema svemu što znamo, svemir je započeo postojati prije konačno mnogo vremena, no barem nije očito da ne bi bio moguć svemir s beskonačnom prošlošću; možda bi mogao biti slučaj da je svemir zapravo multiverzum, aglomerat sastavljen od mnoštva kauzalno izoliranih lokalnih svemira, no čak i ako svemir jest multiverzum, svakako bi to mogao ne biti. Konačno, djeluje bjelodanim da bi svijet mogao biti takvim da svemir uopće ne postoji, da ima mogući svijet u kojem ne postoje nikakvi fizički ni općenito kontingentni entiteti.

Prva središnja tvrdnja leibnizovskoga kozmologijskog argumenta artikulacija je tih modalnih intuicija. Primjerice, u najjednostavnijoj inačici argumenta LK velika je činjenica to da svemir postoji kontingentno, tj. da svemir nije metafizički nužan. ${ }^{10}$ Postoje, međutim, dobri razlozi zašto bi se takva formulacija, ovisno već o smislu u kojem rabimo riječ »svemir«, mogla učiniti preuskom. Primjerice, želimo li sačuvati riječ »svemir« u njezinu uobičajenom značenju za cjelinu fizičke ili prostorno-vremenske stvarnosti, tada, postoje li ne-fizička kontingentna bića (poput npr. anđela), »svemir« ne referira na maksimalnu kontingentnu činjenicu - drugim riječima, svemir ne obuhvaća sveukupnost kontingentne stvarnosti. U tom slučaju, međutim, primjena prikladnoga eksplanacijskog ili kauzalnog načela na sâm svemir - načela, recimo, da svako kontingentno biće ima objašnjenje svoje opstojnosti u nekom vanjskom uzroku - ne bi jamčila da objašnjenje ili uzrok svemira leži u nekom nekontingentnom, tj. nužnom biću, kako se argumentom LK pokušava pokazati. No, dakako, odgovor na pitanje je li argument LK uspješan ne ovisi o tome postoje li anđeli ili ne. Štoviše, uspješnost argumenta LK ne ovisi ni o tome postoji li fizička stvarnost i u kojem točno smislu. Usvajanje antirealističke metafizičke teorije - određene vrste subjektivnoga idealizma, recimo - prema kojoj bi nekoj vrsti mentalnih ili idealnih entiteta (idejama, predodžbama, osjetilnim podatcima i sl.) pripadalo ontologijsko i eksplanacijsko prvenstvo ili čak prema kojoj fizička stvarnost ne bi uopće postojala, ne može sámo po sebi blokirati argument

10 Vidi npr. William Lane CRAIG, Reasonable Faith, 106-111. Doduše, Craig tu tvrdnju ne iznosi kao eksplicitnu premisu u svojem prikazu osnovne strukture leibnizovskoga argumenta (Isto, 106), no njezina obrana (Isto, 108-110) tvori glavni dio opravdanja premise da ako svemir ima objašnjenje svoje opstojnosti, to je objašnjenje Bog. 
LK (barem u njegovu egzistencijskom stadiju), dok god se dopušta da su barem neki od entiteta koje teorija u pitanju postulira i sami kontingentni. Imajući to na umu, prednost bismo mogli dati nekoj od alternativnih formulacija argumenta u kojima je prva središnja tvrdnja eksplicirana u terminima koji su metafizički neutralniji spram pitanjā o tome koje točno vrste entiteta konstituiraju kontingentnu stvarnost. ${ }^{11}$ Maksimalnu kontingentnu činjenicu - tj. veliku činjenicu opstojnost koje se tvrdi prvom središnjom tvrdnjom argumenta LK - mogli bismo tako, ovisno već o preferiranom konceptualnom okviru i ontologijskom ukusu, opisati radije kao, primjerice, mereologijsku sumu svih potpuno kontingentnih činjenica, ${ }^{12}$ kao konjunkciju svih kontingentno istinitih propozicija, ${ }^{13}$ kao maksimalno kontingentno stanje stvari i sl. ${ }^{14}$

Prva je središnja tvrdnja argumenta LK, dakle, tvrdnja o opstojnosti maksimalne kontingentne činjenice, $\mathrm{tj}$. činjenice koja u nekom primjerenom smislu sadržava, obuhvaća ili povlači svaku kontingentnu činjenicu relevantne vrste. Ovisno o konkretnoj inačici argumenta, maksimalna kontingentna činjenica može biti, recimo, konfiguracija svih kontingentnih predmeta, aglomerat svih potpuno kontingentnih situacija, konjunkcija svih kontingentno

11 Naravno, mogli bismo umjesto toga jednostavno stipulirati da se u kontekstu argumenta riječ svemir ima razumjeti tako da se odnosi na sveukupnost kontingentne stvarnosti, neovisno o tome koje vrste entiteta nju u konačnici konstituirale.

12 Vidi npr. formulaciju argumenta LK u Robert C. KOONS, A New Look at the Cosmological Argument. Potpuno kontingentne činjenice Koons definira kao aktualno postojeće činjenice koje kao svoj mereologijski dio ne sadržavaju nijednu metafizički nužnu činjenicu. Usp. Isto, 195. Iako Koons povlači oštru razliku između činjenica s jedne i propozicija s druge strane - činjenicama naziva »stvari u svijetu koje čine određene propozicije istinitima, a druge neistinitima « $($ Isto, 195) - naglašava da u kontekstu njegova argumenta nema razloga razlikovati između činjenicā, događajā i stanjā stvarī »dok god se o svima njima misli kao o konkretnim dijelovima svijeta", Isto, 196. Izlažući isti argument u Robert C. KOONS, Realism Regained. An Exact Theory of Causation, Teleology, and the Mind, New York, 2000., 107-119, kao i drugdje u knjizi, Koons za ono što u članku naziva činjenicama, dosljedno rabi termin situacija.

13 Formulacija argumenta LK u terminima tzv. velike konjunktivne kontingentne činjenice, tj. konjunkcije svih kontingentno istinitih propozicija, može se naći npr. u Richard M. GALE - Alexander R. PRUSS, A New Cosmological Argument, u: Religious Studies, 35 (1999.) 4, 461-476 i Alexander R. PRUSS, The Leibnizian Cosmological Argument. Uočimo da, govoreći o činjenicama, Gale i Pruss, za razliku od Koonsa (vidi bilj. 12), nemaju na umu situacije, tj. konkretne dijelove svijeta koji čine propozicije istinitima ili neistinitima, već same istinite propozicije.

14 Zanimljiv kozmologijski argument u terminima stanjā stvarī - preciznije, u terminima maksimalnoga kontingentnog stanja egzistencije, tj. maksimalnoga mogućeg stanja stvarī da neke kontingentne pojedinačnosti postoje - može se naći u: Joshua RASMUSSEN, From States od Affairs to a Necessary Being, u: Philosophical Studies, 148 (2010.) 2, 183-200. Pritom stanja stvarī Rasmussen ne razumije kao situacije ili činjenice u Koonsovu smislu (vidi bilj. 12), već kao sui generis vrstu apstraktnih entiteta à la Plantinga. Usp. npr. Alvin PLANTINGA, The Nature of Necessity, New York, 1974. 
istinitih propozicija itd. Prihvati li se postojanje maksimalne kontingentne činjenice, konstrukcija dokaza opstojnosti metafizički nužnoga prvog uzroka primjenom odgovarajućega eksplanacijskog ili kauzalnog načela (i uz pomoć odgovarajućega načela regularnosti) stvar je relativno rutinske tehničke vježbe. ${ }^{15}$ Jedna je od strategija za napad na argument LK stoga pokušati osporiti tu tvrdnju, tj. argumentirati da maksimalna kontingentna činjenica u pitanju ne postoji. Uklanjanjem maksimalne kontingentne činjenice iz ontologije, mogao bi se ponadati kritičar, automatski bi se blokirao argument LK.

\section{Prigovor maksimalnosti}

Dva su načelna načina na koja se može pokušati napasti tvrdnju da postoji maksimalna kontingentna činjenica. Prvi je prihvatiti da postoje kontingentne činjenice relevantne vrste (kontingentne propozicije, situacije i sl.) i dopustiti da one, u skladu s prikladnim eksplanacijskim ili kauzalnim načelom, doista imaju objašnjenje ili uzrok odgovarajuće vrste, ali pritom zanijekati da postoji nešto poput maksimalne kontingentne činjenice, tj. kontingentne činjenice koja bi obuhvaćala, sadržavala ili implicirala svaku pojedinu kontingentnu činjenicu. Otprilike kao što u standardnim aksiomatskim teorijama skupova ne postoji skup svih skupova, nijedna činjenica koja bi sadržavala svaku pojedinu kontingentnu činjenicu ne bi bila legitimna cjelina - radilo bi se o takoreći tek prividnoj, nepostojećoj sveukupnosti - te stoga metafizičko načelo u pitanju ne bi bilo legitimno primjenjivo na nju, odnosno bilo bi pogrešno (ili čak besmisleno) tvrditi da i ona sama mora imati objašnjenje ili uzrok.

Koliko bi takav odgovor na argument LK mogao početno djelovati plauzibilnim ovisi, dakako, o konkretnoj inačici argumenta - preciznije, o tome

15 Dakako, da bi se eksplanacijsko ili kauzalno načelo u pitanju moglo legitimno primijeniti na maksimalnu kontingentnu činjenicu, ona bi morala biti u relevantnom smislu iste vrste kao i njezine sastavnice, tj. ona bi i sama morala posjedovati ona svojstva koja opravdaju primjenu toga načela i time biti uključena u kolekciju činjenica na koje se načelo u pitanju odnosi. Drugim riječima, primjenom načela na maksimalnu kontingentnu činjenicu ne bi se smjelo počiniti tzv. pogrešku kompozicije. Primjerice, da bi načelo prema kojem svaka kontingentno istinita propozicija ima objašnjenje bilo primjenjivo na konjunkciju svih kontingentno istinitih propozicija, ta bi konjunkcija i sama morala biti kontingentno istinita propozicija; da bi se načelo prema kojem svaka potpuno kontingentna situacija ima uzrok moglo primijeniti na mereologijsku sumu svih potpuno kontingentnih situacija, ta bi suma i sama morala biti potpuno kontingentna situacija. Da maksimalna kontingentna činjenica doista posjeduje željena svojstva obično nije teško pokazati. U slučaju konjunkcije kontingentnih propozicija dokaz je trivijalan, dok za dokaz u slučaju agregata potpuno kontingentnih situacija vidi dokaz leme 8.3 u: Ro- 
koja vrsta entiteta u njoj ima ulogu maksimalne kontingentne činjenice - no ne čini se da se njime može uspješno blokirati argument, iako bi se možda u pojedinim slučajevima tvrdnja o postojanju maksimalne kontingentne činjenice morala na određene načine modificirati kako bi se prigovor izbjegao. Na primjer, $\mathrm{u}$ inačici argumenta LK koju su razvili Richard Gale i Alexander Pruss maksimalna kontingentna činjenica jednostavno je konjunkcija svih kontingentno istinitih propozicija, tj. ono što Gale i Pruss nazivaju »velika konjunktivna kontingentna činjenica« (BCCF) ${ }^{16}{ }^{\text {No, }}$ zašto misliti da postoji zasebna propozicija koja je konjunkcija svih kontingentno istinitih propozicija ako već znamo da ne postoji skup svih kontingentno istinitih propozicija? ${ }^{17}$ Naravno, konjunkcije propozicija nisu isto što i skupovi propozicija te iz toga što određena kolekcija propozicija ne tvori skup ne slijedi izravno da ne postoji konjunkcija svih propozicija te kolekcije, ali u najmanju ruku barem nije posve očito da konjunkcija u pitanju postoji. Štoviše, čini se da imamo dobre razloge vjerovati da BCCF doista ne postoji. Kako BCCF, po pretpostavci, uključuje sve kontingentno istinite propozicije, među njezinim se konjunktima ne nalaze samo propozicije koje izražavaju negeneralizirana pozitivna stanja stvari ili situacije, tj. propozicije da pojedini predmeti posjeduju određena svojstva ili da pojedini predmeti međusobno stoje u određenim relacijama (poput npr. propozicije da je Sokrat mudar) već također i negativne propozicije (npr. propozicija da Sokrat nije sofist), generalizirane propozicije (primjerice propozicija da postoji barem jedan predmet koji nije sofist), kao i propozicije proizvoljno visokih redova (propozicija, recimo, da nije istinita propozicija da je neistinita propozicija da postoji barem jedan predmet koji nije sofist). Također, pretpostavka da postoji BCCF obvezuje na prihvaćanje opstojnosti beskonačnih propozicija, tj. propozicija sastavljenih od beskonačno mnogo potpropozicija - BCCF sáma jedna je takva propozicija - a time se čini legitimnim govoriti i o propozicijama koje su same svoje potpropozicije (bez obzira postojale takve propozicije ili ne). To, međutim, čini opravdanim strah da bi pretpostavka o postojanju BBCF-a mogla voditi, možda pomoću nekoga oblika cantorovske dijagonalne

16 Usp. Richard M. GALE - Alexander R. PRUSS, A New Cosmological Argument. Gale i Pruss napominju (u bilj. 2) da velika konjunktivna činjenica ne sadržava istinitosno-funkcijske redundantnosti i da je to ograničenje »nužno da bi se izbjegla apsurdnost da je konjunkcija jedan od svojih vlastitih konjunkata«, Isto, 462. Pruss u kasnijim radovima više ne ustraje na tom uvjetu, već samo piše da je BCCF konjunkcija svih kontingentno istinitih propozicija, »možda s uklonjenim logičkim redundantnostima«. Usp. Alexander R. PRUSS, The Principle of Sufficient Reason, 97; Alexander R. PRUSS, The Leibnizian Cosmological Argument, 50.

17 Vidi bilj. 3. 
konstrukcije, nekoj vrsti logičkih ili semantičkih paradoksa. ${ }^{18}$ Doista, u svojoj kritici Gale-Prussova argumenta, Kevin Davey i Rob Clifton, dijagonalnim argumentom strukturalno donekle sličnim konstrukciji glasovitoga Russellova paradoksa o skupu svih skupova koji nisu sami svoji članovi, ponudili su uvjerljiv reductio ad absurdum da BCCF ne postoji. Preciznije, Davey i Clifton pokazali su da ako bi $p$ bila konjunkcija svih kontingentno istinitih propozicija koje nisu same svoje potpropozicije, tada bi propozicija $E(p)$, tj. propozicija da $p$ ima objašnjenje, morala ujedno i biti i ne biti potpropozicija same sebe. No ako postoji BCCF, čini se da bi morala postojati i njezina potkonjunkcija koje su konjunkti upravo oni konjunkti BCCF-a koji sami nisu svoje potpropozicije. Pretpostavka o postojanju konjunkcije svih kontingentno istinitih propozicija stoga bi vodila protuslovlju. ${ }^{19}$

Međutim, samim time stvar još nije izgubljena za Gale-Prussov kozmologijski argument. Kako Davey i Clifton sami primjećuju, za argument nije potrebno da postoji propozicija koja sadržava svaku kontingentno istinitu pro-

18 Aludira se na metodu kojom je Georg Cantor dokazao svoj slavni teorem da je kardinalni broj partitivnoga skupa skupa $S$ uvijek strogo veći od kardinalnoga broja skupa $S$ pokazavši da pretpostavka o postojanju bijekcije između skupa $S$ i njegova partitivnoga skupa vodi protuslovlju. Metoda je česta u matematici i logici i u osnovi je konstrukcije mnogih slavnih antinomija, primjerice Russellova paradoksa.

19 Usp. Kevin DAVEY - Rob CLIFTON, Insufficient Reason in the 'New Cosmological Argument', u: Religious Studies, 37 (2001.) 4, 485-490. Slično načinu na koji Russellov paradoks pokazuje da je protuslovan pojam skupa svih skupova koji nisu svoji vlastiti elementi, Davey-Cliftonov argument pokazuje da je protuslovan pojam konjunkcije svih kontingentno istinitih propozicija koje nisu svoje vlastite potpropozicije. Argument, doduše, nije konkluzivan argument da BCCF ne postoji. Kako napominje Pruss, strogo gledano, argument samo pokazuje da ne postoji propozicija koja je konjunkcija svih kontingentno istinitih propozicija koje nisu same svoje podpropozicije, ne da ne postoji konjunkcija svih kontingentno istinitih propozicija simpliciter. Da bi iz argumenta slijedilo da BCCF ne postoji potrebna je dodatna pretpostavka da je za svaku konjunktivnu propoziciju svaka njezina potkonjunkcija također propozicija. No ta pretpostavka nije trivijalna. Naime, kako kolekcija svih kontingentno istinitih propozicija ne tvori skup, jednako kao što ne možemo ležerno govoriti o proizvoljnim potkolekcijama kontingentno istinitih propozicija, ne možemo ni o proizvoljnim potkonjunkcijama. Stoga, smatra Pruss, »dani kandidat za propoziciju trebao bi se smatrati nevinim dok mu se ne dokaže krivnja«, Alexander R. PRUSS, The Principle of Sufficient Reason, 100, a Davey-Cliftonov argument sâm BCCF ostavlja nevinim. To se čini branjivim odgovorom. Uostalom, postoje teorije skupova (primjerice, Quineova NF) u kojima postoji skup svih skupova iako, dakako, ne postoji skup svih skupova koji sami nisu svoji elementi. Usp. Willard Van Orman QUINE, New Foundations for Mathematical Logic, u: Willard Van Orman QUINE, From a Logical Point of View, Cambridge - London, 2003., 92. S druge strane, priznaje Pruss, ako već ne postoji konjunkcija svih propozicija koje imaju svojstvo da su kontingentno istinite i nisu svoje vlastite propozicije, zašto misliti da postoji konjunkcija propozicija sa svojstvom da su kontingentno istinite? Usp. Alexander R. PRUSS, The Principle of Sufficient Reason, 100. 
poziciju kao svoj konjunkt, već samo propozicija koja logički povlači svaku kontingentno istinitu propoziciju. ${ }^{20}$ Doista, lako je vidjeti da općenito $\mathrm{u}$ argumentima LK sama razlika između toga sadržava li maksimalna kontingentna činjenica sve kontingentne činjenice (relevantne vrste) ili ih pak samo povlači ima relativno malu ulogu. Primjerice, neka je $p$ kontingentno istinita propozicija, takva da za svaku kontingentno istinitu propoziciju $q, p$ povlači $q(q$ pritom može, ali ne mora biti konjunkt $\mathrm{u} p$ ). Neka je istinito neko prikladno eksplanacijsko načelo - načelo dostatnoga razloga, recimo - prema kojem svaka kontingentno istinita propozicija ima objašnjenje. Neka je objašnjenje propozicije $p$ propozicija $r$. Plauzibilno, ako je $r$ objašnjenje kontingentno istinite propozicije $p$, a $p$ povlači $q$, tada $r$ ujedno objašnjava i $q .{ }^{21}$ Slijedilo bi, dakle, da postoji propozicija koja objašnjava svaku kontingentno istinitu propoziciju. Argument da to objašnjenje mora uključiti kauzalno djelovanje nekoga metafizički nužno opstojećega slobodnog činitelja dalje bi slijedio kao i u slučaju propozicije BCCF.22

Time je otvorena mogućnost ograničavanja konjunkata maksimalne kontingentne činjenice Gale-Prussova argumenta na neku potkolekciju kontingentno istinitih propozicija koja bi bila »dovoljno velika« za izvođenje svih kontingentnih istina, no ujedno ne "prevelika« da konjunkcija njezinih članova ne bi tvorila propoziciju. U svojem odgovoru Daveyju i Cliftonu Gale i Pruss tako za veliku konjunktivnu kontingentnu činjenicu predlažu, umjesto BCCF, propoziciju $\mathrm{BCCF}^{*}$, koja je konjunkcija svih kontingentno istinitih atomarnih propozicija, svih istinitih propozicija koje se nalaze u objašnjenjima osnovnih propozicija (ili njihovih konjunkcija) i svih istinitih osnovnih propozicija koje

20 Usp. Kevin DAVEY - Rob CLIFTON, Insufficient Reason in the 'New Cosmological Argument', 487.

${ }_{21}$ U slučaju BCCF-a dovoljno bi bilo kazati da ako $r$ objašnjava $p$, onda objašnjava i svaki konjunkt u p. Dakako, u oba slučaja to ne vrijedi za djelomična objašnjenja. No učini li se naša tvrdnja spornom i za potpuna objašnjenja - objašnjenje, uostalom, nije isto što i povlačenje i irelevantnosti u objašnjenju možda mogu »pokvariti« objašnjenje na način na koji ne mogu naštetiti logičkomu izvodu - ona se može ublažiti u tvrdnju, primjerice, da $r$ sadržava sve potrebne resurse za objasniti $q$. Argument se dalje nastavlja analogno, a kako u malo drukčijem kontekstu ističe Pruss, »što god je bilo plauzibilno prije, ostat će plauzibilnim«, Alexander R. PRUSS, The Leibnizian Cosmological Argument, 50.

22 Za detaljniji opis strukture samoga argumenta vidi: Isto, 77-78. Izvorni Gale-Prussov argument nešto je složeniji jer rabi modalno oslabljenu inačicu načela dostatnoga razloga, tzv. slabo načelo dostatnoga razloga (W-PSR), prema kojem (nužno) za svaku kontingentno istinitu propoziciju vrijedi da je metafizički moguće da ona ima objašnjenje, tj. prema kojem (nužno) za svaku istinitu propoziciju $p$ postoji neki mogući svijet u kojem $p$ ima objašnjenje (usp. Richard M. GALE - Alexander R. PRUSS, A New Cosmological Argument, 463). Načelo je formulirano tako da vrijedi za svaki mogući svijet, ali taj uvjet nužnosti nije potreban za sam argument. 
izražavaju kauzalne relacije. ${ }^{23}$ Kako je plauzibilno da, za razliku od BCCF, nije slučaj da bi za svaku potkonjunkciju $p$ propozicije $\mathrm{BCCF}^{*}$ svaka kontingentno istinita propozicija višega reda koja supervenira na $p$ - primjerice propozicija $E(p)$ da $p$ ima objašnjenje, propozicija $T(p)$ da je $p$ istinita i sl. - morala i sama biti jedan od konjunkata u $B C C F^{*}$, ne čini se da je za $\mathrm{BCCF}^{*}$ moguće konstruirati argument analogan onomu Daveya i Cliftona. ${ }^{24}$ Štoviše, čini se plauzibilnim da kolekcija propozicija koje Gale i Pruss predlažu kao konjunkte modificirane velike konjunktivne kontingentne činjenice tvori skup i da stoga doista postoji propozicija koja je konjunkcija svih propozicija te kolekcije, tj. BCCF*. Također, plauzibilno je da $\mathrm{BCCF}^{*}$ logički povlači svaku kontingentno istinitu propoziciju, odnosno da svaka kontingentna istina supervenira na nekoj njezinoj potkonjunkciji. ${ }^{25}$ Ako jest tako, BCCF ${ }^{*}$ je dovoljna za pokretanje argumenta LK.

23 Usp. Richard M. GALE - Alexander R. PRUSS, A Response to Oppy, and to Davey and Clifton, 95. Gale i Pruss napominju da će točan način na koji valja ograničiti BCCF ovisiti o pozadinskim ontologijskim razmatranjima. $\mathrm{BCCF}^{*}$ koju predlažu, primjerice, pretpostavlja ontologiju koja uključuje atomarne propozicije. Pruss pojašnjava da se osnovnim (basic) propozicijama mogu smatrati one kojih istinitost ne ovisi o istinitosti nekih drugih, osnovnijih propozicija. Usp. Alexander R. PRUSS, The Leibnizian Cosmological Argument, 80. Pruss na drugom mjestu iznosi nešto drukčiji (i prima facie općenitiji) prijedlog za ograničenje velike konjunktivne kontingentne činjenice na konjunkciju svih kontingentno istinitih osnovnih propozicija i svih logički jednostavnih (uncompounded) propozicija koje izražavaju kauzalne relacije. Usp. Alexander R. PRUSS, The Principle of Sufficient Reason, 101. Također, čini se da bi se BCCF mogla ograničiti jednostavno na konjunkciju svih kontingentnih propozicija prvoga reda (s uklonjenim logičkim redundantnostima), ali tada bi za argument LK bilo potrebno modificirati i eksplanacijsko načelo tako da se njime zahtijeva da svaka kontingentno istinita propozicija prvoga reda ima (moguće) objašnjenje prvoga reda. Usp. Isto, 237-238.

24 Trivijalno je da je $T(p)$ kontingentno istinita propozicija ako i samo ako je $p$ kontingentno istinita propozicija, no tvrdnja da je propozicija $E(p)$ kontingentno istinita ako je $p$ kontingentno istinita pretpostavlja odgovarajuće eksplanacijsko načelo, primjerice ono da svaka kontingentno istinita propozicija ima objašnjenje. Davey i Clifton iznose svoj argument kao reductio eksplanacijskoga načela u Gale-Prussovu argumentu, tj. kao argument protiv slaboga načela dostatnoga razloga (vidi bilj. 22), te je stoga Davey-Cliftonov argument formuliran u terminima priroka 'E' (usp. Kevin DAVEY - Rob CLIFTON, Insufficient Reason in the 'New Cosmological Argument', 486-487). Međutim, pitanje istinitosti eksplanacijskoga načela može se u kontekstu rasprave o opstojnosti velike konjunktivne kontingentne činjenice ostaviti po strani i argument parafrazirati u terminima priroka 'T'. Usp. Alexander R. PRUSS, The Principle of Sufficient Reason, 99-100.

25 Da bi kolekcija propozicija koje Gale i Pruss predlažu kao konjunkte BCCF*-a doista tvorila konjunktivnu propoziciju i ujedno povlačila sve ostale kontingentno istinite propozicije možda je potrebno prikladno načelo regularnosti. Naime, kako u malo drukčijem kontekstu primjećuje Jacob Ross (govoreći o Prussovu prijedlogu BCCF*-a iz The Principle of Sufficient Reason), da bi sve kontingentno istinite propozicije supervenirale na $\mathrm{BCCF}^{*}$-u osnovne se propozicije moraju shvatiti dovoljno široko da uključe i propozicije koje izražavaju (ne-humeovske) zakone prirode, ali tada nemamo jamstva da tih osnovnih propozicija ima dovoljno malo da tvore skup - a time ni jamstva da osnovne 
Neovisno o tome može li neka (primjereno ograničena) konjunkcija kontingentnih propozicija imati ulogu maksimalne kontingentne činjenice $\mathrm{u}$ argumentu LK, postoje inačice argumenta u kojima se predložene maksimalne kontingentne činjenice ne čine posebno problematičnima. Na primjer, u formalizaciji kozmologijskoga argumenta koju je iznio Robert Koons maksimalna je kontingentna činjenica situacija koja je agregat svih potpuno kontingentnih situacija, tj. svih situacija koje kao svoj mereologijski dio ne sadržavaju nužne situacije. ${ }^{26}$ Termin »situacija« Koons pritom rabi za bilo koji »stvarni, konkretni dio svijeta, koji čini određene propozicije istinitima, a druge propozicije neistinitima « ${ }^{27}$. Situacije su konkretni događaji i stanja, relata kauzalnih relacija, ne apstraktni entiteti poput propozicija. Pojedini konkretan događaj bacanja cigle u prozor i događaj razbijanja toga prozora situacije su koje međusobno stoje u uzročno-posljedičnom odnosu; stanje Sokratova bivanja mudrim

propozicije u pitanju tvore konjunkciju. Naime, prema Rossu, mogao bi biti slučaj da za svaki skup zakona prirode postoji neki daljnji zakon prirode, različit od njih, koji objašnjava konjunkciju zakona iz toga skupa, iz čega slijedi da ne postoji skup svih zakona prirode. Usp. Jacob ROSS, The Principle of Sufficient Reason and the Grand Inexplicable, u: Tyron Goldschmidt (ur.), The Puzzle of Existence. Why Is There Something Rather Than Nothing, New York - London, 2013., 80-94, 85-87. Međutim, scenarij koji opisuje Ross upravo je primjer neutemeljene eksplanacijske strukture kakvu bi kozmologijski argument ionako morao odbaciti kao metafizički nemoguću ili barem eksplanacijski nepotpunu. Detaljniji opis i kritiku tzv. iregularističkih odgovora na kozmologijski argument može se naći u: Goran LOJKIĆ, Metafizički krajobraz ateizma, u: Obnova, 12 (2019.) 1, 16-59, 44-53.

26 Tu maksimalnu kontingentnu činjenicu naziva Koons »kozmos«. Kao razlog za ograničenje načela kauzalnosti (a time i maksimalne kontingentne činjenice) na potpuno kontingentne situacije Koons navodi izbjegavanje određenih problema povezanih s beskonačnim regresom situacija višega reda, poput primjerice prigovora kozmologijskomu argumentu koji je iznio James Ross (i kasnije William Rowe) da bi, ako bi svaka kontingentna situacija imala uzrok, prvi uzrok morao uzrokovati i kontingentnu situaciju da prvi uzrok uzrokuje kozmos, kontingentnu situaciju da prvi uzrok uzrokuje da prvi uzrok uzrokuje kozmos i tako ad infinitum. Usp. James F. ROSS, Philosophical Theology, Indianapolis, 1969., 295-304; William L. ROWE, The Cosmological Argument, Princeton, 1975., 108-110. Kako te situacije višega reda nisu potpuno kontingentne - naime, sadržavaju kao svoj dio nužnu situaciju, situaciju postojanja prvoga uzroka - Koonsovo načelo kauzalnosti ne zahtijeva da one imaju uzrok i prigovor beskonačnoga regresa otpada. Usp. Robert C. KOONS, Realism Regained, 107, 118-119. Međutim, ne čini se da je ograničavanje na potpuno kontingentne situacije Koonsu potrebno za odgovor Rossu i Roweu jer, neovisno o tom ograničenju, u njegovoj ontologiji nema spornih situacija višega reda (vidi bilj. 31). Ograničenje je ipak opravdano jer, kako je plauzibilno da nužne situacije same ne mogu biti uzrokovane, barem ne u uobičajenu smislu (usp. Isto, 118), kontingentne situacije imaju uzrok upravo u smislu da njihov potpuno kontingentan dio ima uzrok. Koons napominje da ne pretpostavlja postojanje nužnih situacija - to da one postoje slijedi iz kozmologijskoga argumenta. Usp. Isto, 108, 115.

27 Isto, 37. Koons ponegdje $\mathrm{u}$ istom značenju rabi i riječ činjenica i izraz stanje stvari. Usp. Isto, 4-5. 
situacija je koja čini istinitom propoziciju da je Sokrat mudar. Svaki agregat situacija, tj. svaka ekstenzionalna mereologijska suma situacija, i sâm je situacija. Situacija Sokratova bivanja mudrim i prozorova bivanja razbijenim agregat je situacije Sokratova bivanja mudrim i situacije prozorova bivanja razbijenim, a taj agregat, tj. ta složena situacija, čini istinitom konjunktivnu propoziciju da je Sokrat mudar i prozor razbijen. ${ }^{28}$ Međutim, ne moramo pretpostaviti da svakoj istinitoj propoziciji odgovara neka zasebna situacija, tj. da postoji korespondencija jedan na jedan između situacija i propozicija. Propozicija da Sokrat nije sofist nije istinita time što postoji odgovarajuća »negativna« situacija Sokratova nebivanja sofistom, već zato što ne postoji situacija Sokratova bivanja sofistom. Ne postoji ni »disjunktivna« situacija koje bi odgovarala, primjerice, istinitoj propoziciji da je Sokrat mudar ili su dva i dva pet, kao ni »generalizirana« situacija koja bi odgovarala istinitoj propoziciji da postoji barem jedan predmet koji je mudar - obje te propozicije čini istinitima sama situacija Sokratova bivanja mudrim..$^{29}$ Različite supervenirajuće matematičke, semantičke, etičke i druge istine također ne zahtijevaju postojanje dodatnih zasebnih situacija. ${ }^{30}$ Slično, propozicijama koje izražavaju da pojedine situacije međusobno stoje u kauzalnom odnosu ne uvode se nove situacije »višega reda«. Istinitost takvih propozicija, prema Koonsu, supervenira »na uzroku, učinku i određenim ne-situacijskim istinama o modalnom odnosu između uzroka i učinka«, odnosno »kauzalne istine superveniraju na modalnim i drugim ne-kauzalnim

28 Agregat je cjelina koja nije »ništa više« od sume svojih dijelova, tj. cjelina koja ne ovisi o posebnim relacijama između dijelova te cjeline. Agregat svih dijelova koji tvore ovu šalicu na stolu ostaje isti agregat čak i ako su njegovi dijelovi rasuti po podu i šalica više ne postoji kao zaseban predmet. Postojanje agregata proizvoljnih dijelova zajamčeno je aksiomatskom shemom neograničene sume opće ekstenzionalne mereologije. Usp. Achille VARZI, Mereology (13. II: 2016.), u: https://plato.stanford.edu/entries/mereology/ (4. IX. 2020.). Postojanje agregata situacija stoga je vrlo slaba pretpostavka, koja ne zahtijeva da su situacije u agregatu prostorno-vremenski ili kako drukčije međusobno povezane. S druge strane, tvrdnja da je svaki agregat situacijā ujedno i sam zasebna situacija mogla bi se učiniti spornom. Odnosno, mogao bi tko ustrajati na tome da dvije situacije, da bi bile dijelovi iste situacije, moraju uzajamno stajati u odgovarajućem odnosu (biti prostorno-vremenski povezane, recimo). Međutim, pretpostavka da svaki agregat situacija tvori zasebnu situaciju nije nužna za Koonsov kozmologijski argument i cijeli se argument može parafrazirati bez te pretpostavke. Doduše, moralo bi se (prividno) osnažiti relevantno kauzalno načelo u tvrdnju da svaki agregat potpuno kontingentnih situacija ima uzrok (a ne samo da svaka potpuno kontingentna situacija ima uzrok), no to ne djeluje kao sporan potez: ako situacija stajanja šalice na stolu ima uzrok i situacija stajanja knjige na polici ima uzrok, onda i agregat tih situacija ima uzrok (naime, agregat situacija koje su uzroci spomenutih dviju situacija), neovisno o tome tvore li ti agregati sámi zasebne situacije.

29 Usp. Robert C. KOONS, A New Look at the Cosmological Argument, 194-195.

30 Usp. Isto. 
istinama «. ${ }^{31}$ Postojanje agregata svih potpuno kontingentnih situacija stoga ne djeluje pretjerano filozofijski spornim - u svakom slučaju, maksimalnoj kontingentnoj činjenici Koonsova argumenta ne prijeti opasnost od metafizičkih čudovišta analognih konjunkciji svih propozicija koje nisu svoje potpropozicije. Slično vrijedi i za maksimalne kontingentne činjenice nekih drugih formulacija argumenta LK. ${ }^{32}$

Konačno, moguće je formulirati argument LK (ili barem njemu srodan kozmologijski argument) na način da nas njegova maksimalna kontingentna činjenica ne obvezuje na postojanje neke cjeline kontingentnih činjenica kao zasebnoga entiteta - primjerice, na postojanje konjunkcije kontingentnih propozicija, agregata kontingentnih situacija i sl. U inačici egzistencijskoga stadija argumenta LK koju su razvili Alexander Pruss i Joshua Rasmussen - tj. u argumentu koji su nazvali »argument iz kontingentne opstojnosti« - maksimalnoj kontingentnoj činjenici odgovara kontingentno istinita propozicija da, uzevši u obzir sve kontingentne konkretne stvari koje postoje, upravo te stvari postoje. ${ }^{33}$ Istinitost te propozicije ontologijski ne obvezuje na opstojnost nekoga zasebnog entiteta (skupa, recimo, ili agregata) koji u ovom ili onom smislu sadržava sve kontingentne konkretne stvari. Sve što se tvrdi jest da ujedno postoje sve kontingentne konkretne stvari, da ima množina svih kontingentnih konkretnih stvari - množina koja se ne mora shvatiti kao dodatan entitet koji postoji uz same entitete te množine. ${ }^{34} \mathrm{No}$, dakako, i dalje je legitimno pitati za

31 Robert C. KOONS, Realism Regained, 119. Razlikovanje između situacija (koje jedine mogu stajati u kauzalnim relacijama) i na njima supervenirajućih istina omogućuje Koonsu blokirati neke od standardnih prigovora kozmologijskomu argumentu. Pitati što uzrokuje situaciju da prvi uzrok uzrokuje agregat svih potpuno kontingentnih situacija besmisleno je jer, iako propozicija da prvi uzrok uzrokuje kozmos jest istinita kontingentna propozicija, jednostavno ne postoji situacija (višega reda) koja korespondira toj propoziciji (vidi bilj. 26). Sličnu razliku, iz donekle sličnih razloga, između »činjenica« s jedne i istinitih propozicija s druge strane, tj. razlikovanje »ukupnosti instancijacija fundamentalnih svojstava i relacija - što je ništa drugo do konkretna stvarnost sáma - od mnogih propozicija koje su time učinjene istinitima«, povlači i Timothy O'Connor u svojoj inačici argumenta LK. Usp. Timothy O'CONNOR, Theism and Ultimate Explanation, 84.

32 Primjerice Rasmussenove (Joshua RASMUSSEN, From States od Affairs to a Necessary Being) i O'Connorove (Timothy O'CONNOR, Theism and Ultimate Explanation). Vidi bilj. 14 i 31.

33 Usp. Alexander R. PRUSS - Joshua L. RASMUSSEN, Necessary Existence, Oxford, 2018. 34. Eksplicitna premisa njihova argumenta glasi da ako ta propozicija ima objašnjenje, postoji neka nužna konkretna stvar. Pruss i Rasmussen za istinite propozicije dosljedno rabe termin činjenica.

34 »Trik« je u tome da se propozicija o kojoj je riječ valja shvatiti ne u smislu standardne logičke teorije kvantifikacije nego u svjetlu tzv. teorije pluralne kvantifikacije, koja nam omogućuje referirati istovremeno na više predmeta bez pretpostavljanja da ti predmeti, uzeti zajedno, konstituiraju neki daljnji zaseban predmet. Precizan formalni zapis pro- 
objašnjenje spomenute propozicije i time argumentirati da to objašnjenje mora referirati na neko nekontingentno, tj. metafizički nužno biće. Ako su Pruss i Rasmussen $\mathrm{u}$ pravu, njihov argument $\mathrm{u}$ samom korijenu izbjegava raspravu o tome uključuje li maksimalna kontingentna činjenica metafizički problematične cjeline.

\section{Prigovor kontingentnosti}

Drugi, radikalniji način na koji se može pokušati napasti tvrdnju o postojanju maksimalne kontingentne činjenice jednostavno je kazati da maksimalna kontingentna činjenica ne postoji zato što, unatoč prividu naših modalnih intuicija, kontingentne činjenice uopće ne postoje. ${ }^{35}$ Nema konjunkcije svih kontingentno istinitih propozicija jer nijedna propozicija nije kontingentno istinita; nema agregata svih potpuno kontingentnih situacija jer nema situacije koja je kontingentna; nema množine svih kontingentnih entiteta jer sve što postoji, postoji nužno. Primjerice, u jednoj varijanti toga odgovora, mogao bi tko tvrditi da su fundamentalni fizički entiteti i zakoni prirode, koji god oni bili - entiteti i zakoni, recimo, postulirani nekom idealnom »konačnom« fizikalnom »teorijom svega« - metafizički nužni, u smislu da nema mogućega svijeta u kojem bi postojala neka drukčija kolekcija fundamentalnih entiteta i u kojem bi vrijedili neki drukčiji fundamentalni zakoni, a da je sve ostalo što postoji tek deterministički učinak tih fundamentalnih entiteta i zakona. ${ }^{36}$ Što god postojalo, postoji stoga metafizički nužno. Što god bilo slučaj, metafizički je nužno da upravo to jest slučaj. Svijet ne bi mogao biti drukčijim nego što jest - ovo je jedini mogući svijet.

Jedan je od problema s takvim odgovorom na argumente LK to što, ne prihvati li se unaprijed postojanje metafizički ili čak apsolutno nužnoga prvog uzroka, zajedno sa standardnim katalogom atributa koji slijede iz njegove nužne opstojnosti, tvrdnja da su fizički entiteti i zakoni metafizički nužni ne djeluje uopće inteligibilnom, kamoli branjivom. Kazavši to ne odbacujemo

pozicije stoga ne sadrži samo standardne »singularne« količitelje klasične logike već i njihove "pluralne« parnjake. Usp. Isto, 34 .

35 Zapravo, kako se tipično smatra da su eksplanacijska/kauzalna načela i načela regularnosti argumenata LK, ako su istinita, metafizički nužno istinita, potrebna je nešto jača tvrdnja da kontingentne činjenice ne samo da ne postoje nego da ne bi ni mogle postojati.

36 Uočimo da tvrdnja da je sve ostalo što postoji tek (deterministički) učinak metafizički nužnih fundamentalnih fizičkih entiteta i zakona prirode povlači da ne postoji transcendentni prvi uzrok - u predloženom bi odgovoru na argument LK sami fundamen- 
necesitarijanizam per se. Naprotiv, prihvati li se postojanje prvoga uzroka, nijekanje kontingentnosti svijeta čini se branjivom metafizičkom pozicijom. Primjerice, pretpostavi li se opstojnost metafizički nužnoga prvog uzroka, moglo bi se argumentirati da su, iako naizgled kontingentni, fizički entiteti i zakoni prirode također metafizički nužni utoliko što su rezultat nužne emanacije iz prvoga uzroka ili pak zato, recimo, što prvi uzrok zbog svoje savršene dobrote nužno stvara najbolji mogući svijet. No, dakako, ti argumenti nisu na raspolaganju onomu tko napada argument LK nadajući se time osporiti samu tvrdnju o postojanju prvoga uzroka. Želi li se zanijekati postojanje kontingentnih činjenica, a ujedno pritom ne prihvatiti unaprijed ono što se samim argumentom pokušava dokazati, kritičar argumenta LK morao bi ponuditi neki o pretpostavci opstojnosti prvoga uzroka neovisan razlog zašto, suprotno našim modalnim intuicijama, fizičke entitete i zakone prirode valja smatrati metafizički nužnima. Nevolja je, međutim, u tome što se bez te pretpostavke ne čini da imamo ikakav koliko-toliko jasan pojam o tome na koji bi način fizički entiteti mogli postojati metafizički nužno, a zakoni prirode metafizički nužno biti upravo takvima kakvi jesu. ${ }^{37}$ Štoviše, metafizički nužna opstojnost prima facie implicira svojstva koja djeluju konceptualno nespojivima s bilo čim što bismo bili skloni nazvati fizičkim entitetom. Tako se u identifikacijskom stadiju argumenata LK tipično argumentira da nužna opstojnost prvoga uzroka povlači da prvi uzrok posjeduje niz jedinstvenih atributa koji, između ostaloga, impliciraju da ne može biti riječ o fizičkom predmetu. Detalji se mogu znatno razlikovati od argumenta do argumenta i od autora do autora, no tradicionalno se argumentira da iz njegove nužne opstojnosti slijedi da bi prvi uzrok morao biti actus purus, ipsum esse subsistens, savršeno jednostavan, nužno jedinstven, nepromjenjiv itd. ${ }^{38} \mathrm{Ni}$ za jedno se od navedenih svojstava ne čini da bi ga mogli posjedovati fizički entiteti. Slično, plauzibilnosti (ili barem inteligibilnosti) tvrdnje da bi fizički entiteti mogli metafizički nužno postojati ne može pomoći

37 Kako bi precizniji odgovor na tvrdnju da su zakoni prirode metafizički nužni uključio određena razmatranja povezana s netrivijalnim pitanjima o naravi zakonā prirode i njihova odnosa s fizičkim entitetima i događajima - pitanjima poput onih jesu li zakoni tek generalizirani opisi pravilnosti u sljedovima događajā, superveniraju li zakoni na naravima fizičkih entiteta i njihovim kauzalnim moćima i sl. - ta razmatranja moramo ovdje ostaviti po strani i ograničiti se samo na odgovor na tvrdnju o metafizičkoj nužnosti fizičkih entiteta. Taj je odgovor i sam dovoljan za odbiti opisani napad na maksimalnu kontingentnu činjenicu. Odgovor na analognu tvrdnju o metafizičkoj nužnosti zakona prirode vidi u: Goran LOJKIĆ, Metafizički krajobraz ateizma, 31-33.

38 Usp. Edward FESER, Five Proofs of the Existance of God, San Francisco, 2017., 159-161 za sažet prikaz načina na koje se u tzv. racionalističkom dokazu za Božju opstojnost iz nužne opstojnosti tradicionalno izvode ostali Božji atributi. 
ni pozivanje na apstraktne entitete poput matematičkih predmeta, univerzalija, propozicija i sl. - entitete za koje jest plauzibilno da, ako postoje, postoje metafizički nužno - kao na model prema kojemu bismo mogli razumjeti što bi to značilo da fizički entiteti postoje metafizički nužno. Naime, svojstva koja tipično vezujemo uz apstraktne predmete - i koja opravdavaju smatrati apstraktne predmete metafizički nužnima - uključuju, primjerice, to da oni nisu prostorno ni vremenski lokalizirani, nisu podložni promjeni, ne mogu nastati ni nestati, nematerijalni su, kauzalno inertni i sl. ${ }^{39}$ No nijedno od tih svojstava normalno ne pripisujemo fizičkim entitetima. Ne pretpostavimo li unaprijed postojanje nečega poput prvoga uzroka, nijekanje postojanja kontingentnih činjenica djeluje stoga u najboljem slučaju neinteligibilnim, u najgorem pak slučaju nekoherentnim. ${ }^{40}$

Međutim, čak i ako bismo neovisno o pretpostavci opstojnosti prvoga uzroka mogli pridati neko značenje tvrdnji da su dani fizički entiteti i zakoni prirode metafizički nužni i ako bismo, štoviše, prihvatili da kontingentne činjenice ne postoje - $\mathrm{i}$ time da ne postoji maksimalna kontingentna činjenica - to samo po sebi ne bi učinilo argumente LK neuspješnima niti općenito uklonilo eksplanacijsku potrebu za prvim uzrokom. Iako su argumenti LK standardno formulirani u terminima kontingentnih činjenica, argument se može parafrazirati i bez pretpostavljanja da kontingentne činjenice postoje. Ključ je u sljedećem: čak i ako bi naizgled kontingenti predmeti poput šalice, naizgled kontingentni događaji poput padanja šalice sa stola i naizgled kontingentna stanja poput šaličina bivanja razbijenom bili zapravo metafizički nužnima - u smislu da nema mogućega svijeta u kojem ta šalica nije pala sa stola i razbila se - i dalje bi bilo opravdano pitati za neko daljnje objašnjenje ili uzrok zašto šalica postoji, zašto se dogodilo njezino padanje sa stola, zašto je slučaj da je šalica razbijena. Ako bi doista i bio slučaj da su stvari poput šalica, njihovih padanja sa stolova i njihovih bivanja razbijenima metafizički nužne, ne čini se da bi se time promijenilo to da su takvi predmeti, događaji i stanja ontologijski ovisni o nečemu izvan njih samih. Šalica u pitanju možda postoji u svakom mogućem svijetu, no njezina opstojnost svejedno ovisi o nečem što nije ta šalica sáma - nešto različito od te šalice dovelo do toga da ona postoji, nešto je dru-

39 Kako je često slučaj, stvar je malo složenija no što odajemo tekstom. O problemu definicijskih kriterija za apstraktne entitete vidi u: William Lane CRAIG, God and Abstract Objects. The Coherence of Theism: Aseity, Cham, 2017., 6-13.

40 Detaljnija rasprava o tzv. naivnom necesitizmu, skupini metafizičkih teorija koja uključuje gore razmatran pokušaj blokiranja argumenta LK, može se naći u: Goran LOJKIĆ, Metafizički krajobraz ateizma, 27-33. 
go prouzročilo to da šalica jest. Drugim riječima, čak i ako bi šalica postojala metafizički nužno, ne bi bila riječ o, tradicionalnim rječnikom, nužnoj opstojnosti $a$ se, tj. o nužnoj opstojnosti u apsolutnom ili bezuvjetnom smislu - ako bi šalica i bila metafizički nužnom, bila bi to u nekom uvjetnom ili derivativnom smislu. No onda je očito kako možemo parafrazirati argument LK. Nazovimo pseudokontingentnim činjenicama one činjenice koje - bile kontingentne ili ne - ne postoje nužno a se. Pojam maksimalne kontingentne činjenice poopćimo u pojam maksimalne pseudokontingentne činjenice - ne čini se da se time uvode ikakvi dodatni teorijski problemi uz one koje smo razmatrali u prethodnom odsječku. Argumenti da objašnjenje maksimalne pseudokontingentne činjenice mora referirati na apsolutno nužan prvi uzrok tada su posve analogni onima u standardnim argumentima LK za postojanje prvoga uzroka.

\section{Zaključak}

Razlikovno je obilježje leibnizovskih kozmologijskih argumenata to što uključuju tvrdnju o postojanju maksimalne kontingentne činjenice, tj. kontingentne činjenice koja sadržava ili implicira svaku kontingentnu činjenicu za argument u pitanju relevantne vrste. Napasti tu tvrdnju jedna je od mogućih strategija kojima se može pokušati izbjeći konkluzija argumenta o postojanju metafizički prvoga uzroka. Razmotrili smo dva načelna pristupa opovrgavanju tvrdnje. Prvi je pokušati pokazati da bi postojanje maksimalne kontingentne činjenice ontologijski obvezivalo na postojanje logički ili metafizički nelegitimnih cjelina. Drugi je pristup pokušati osporiti postojanje kontingentnih činjenica općenito. Međutim, pokazali smo da nijedan od tih dvaju pristupa nije uspješan u blokiranju leibnizovskoga argumenta: maksimalne kontingentne činjenice $\mathrm{u}$ većini se inačica argumenta čine logički neproblematičnima i metafizički nevinima, a nijekanje postojanja kontingentnih činjenica u najboljem slučaju djeluje neinteligibilnim prijedlogom, barem ako se njime unaprijed ne zajamči opstojnost nečega poput prvoga uzroka. Konačno, pokazali smo da ni progon kontingentnih činjenica iz ontologije ne bi sam po sebi ugrozio leibnizovske argumente jer bi ih se, bez očitoga gubitka plauzibilnosti, moglo parafrazirati tako da uopće ne pretpostavljaju postojanje kontingentnih činjenica. 


\title{
Summary
}

THE MAXIMAL CONTINGENT FACT IN LEIBNIZ'S COSMOLOGICAL ARGUMENTS

\author{
Goran LOJKIĆ \\ Institute of Philosophy \\ Ulica grada Vukova 54, HR - 10000 Zagreb \\ goran@ifzg.hr
}

Leibniz's cosmological arguments are a class of cosmological arguments for existence of the metaphysical first cause, whose defining characteristic is application of some wider explanatory principle or non-local principle of causality on so-called maximal contingent fact, i.e., contingent fact that contains or implies every contingent fact of the relevant kind. One of the strategies of attack on Leibniz's argument is, therefore, to argue that the respective maximal contingent fact does not exist. The article describes two principal ways in which one might try to carry out this critique. The first is to deny that the maximal contingent fact is the legitimate sum of facts, the second is to deny the existence of contingent facts in general. The article presents a few alternative formulations of the claim of existence of maximal contingent fact, their background theoretical motivation, and manners in which specific formulations avoid critique. The author argues that the forms of critique that are related to the maximal contingent fact are not a serious threat to Leibniz's arguments for the existence of the first cause.

Keywords: cosmological arguments, Leibniz's cosmological argument, contingency, maximal contingent fact, necessary existence, first cause. 